\title{
PENGARUH PENAMBAHAN JAGUNG MANIS (Zea mays saccharata) TERHADAP SIFAT FISIK DAN AKSEPTABILITAS PADA ROLADE TEMPE
}

\author{
Friska Ruswandani Pratiwi ${ }^{1}$ ), Nur Mei Alfi Fajrin 2), Agustiani Putri ${ }^{3)}$ \\ Fakultas Matematika dan Ilmu Pengetahuan Alam \\ Universitas Negeri Jakarta 1)2)3) \\ Email :penelimudaunj@gmail.com
}

\begin{abstract}
ABSTRAK
Rolade menjadi salah satu upaya inovasi pengolahan daging sebagai sumber protein hewani yang tinggi. Namun, di Indonesia konsumsi protein hewani masih tergolong rendah. Hal ini diakibatkan oleh tingginya harga protein hewani, yakni 120 ribu per $\mathrm{kg}$ (liputan6.com, 2016). Salah satu alternatif untuk mengatasi permasalahan ini ialah memberikan alternatif pengganti daging dengan bahan dasar rolade yang tidak mahal namun kandungan gizinya tidak kalah, seperti tempe yang terbuat dari kacang kedelai. Penelitian ini bertujuan untuk menguji pengaruh penambahan jagung manis (Zea Mays Saccharata) terhadap sifat fisik dan akseptabilitas pada rolade tempe. Metode penelitian yang dilakukan ialah Studi literatur, Simple Random Sampling, dan Eksperimen dengan Rancangan Acak Lengkap. Hasil penelitian menunjukkan adanya nilai susut masak dari variasi penambahan jagung manis ialah 49,04\% (perlakuan A0), 27,26\% (perlakuan A1), 25,06\% (perlakuan A3), 12,82\% (perlakuan A5). Selanjutnya uji keempukan menunjukkan hasil 175,20 (perlakuan A0), 170,52 (perlakuan A1), 167,75 (perlakuan A3), 157,39 (perlakuan A5). Tingkat penerimaan konsumen dapat diuji menggunakan uji akseptabilitas yang dilakukan oleh 70 orang mahasiswa S1 UNJ, yaitu 28 orang dari mahasiswa S1 UNJ (KPM) dan 42 orang dari mahasiswa S1 UNJ (nonKPM) yang diambil secara acak di fakultas masing-masing. Perlakuan A3 memberikan hasil yang paling banyak diminati untuk warna, yaitu 152. Perlakuan A0 untuk aroma sebanyak 271, 290 tekstur dari perlakuan A0 mudah diterima konsumen.
\end{abstract}

Kata Kunci : Tempe, Rolade, Jagung Manis

\section{ABSTRACT}

Rolade be one innovation efforts meat processing as a source of animal protein is high. However, Indonesia's animal protein consumption is still relatively low. This is caused by the high price of animal protein, which is 120 thousand per $\mathrm{kg}$ (liputan6.com, 2016). One alternative to overcome this problem is to provide an alternative to meat with Rolade base material that is not expensive but no less nutritional content, such as tempeh is made from soybeans. This study aimed to examine the effect of the addition of sweet corn (Zea Mays Saccharata) on the physical properties and acceptability in Rolade tempeh. The research method is the study of literature, Simple Random Sampling, and experiment with a completely randomized design. Results showed that cooking shrinkage values of addition of sweet corn variety was $49.04 \%$ (treatment A0), $27.26 \%$ (treatment A1), 25.06\% (treatment A3), 12.82\% (treatment A5). Further tests showed results of tenderness 175.20 (treatment A0), 170.52 (treatment A1), 167.75 
(treatment A3), 157.39 (A5 treatment). The level of consumers acceptance can be tested using the acceptability test performed by 70 students S1 UNJ, i.e. 28 people from S1 students UNJ (KPM) and 42 of the students S1 UNJ (non-KPM) taken at random in each faculty. A3 treatment give the best results in great demand for color, ie 152. A0 treatment for aroma as much as 271, 290 texture of treatment A0 easily accepted by consumers.

Keywords: Tempe, Rolade, sweet corn (Zea Mays Saccharata)

\section{PENDAHULUAN}

Rolade merupakan olahan bahan pangan hewani yang terbuat dari campuran daging sapi atau daging ayam yang dicincang dan dicampurkan dengan pati atau tepung dengan atau tanpa tambahan bahan dan bumbu lain yang dibentuk bulat (Rodawati, dkk., 2011). Rolade menjadi salah satu upaya inovasi pengolahan daging sebagai sumber protein hewani yang tinggi. Namun, di Indonesia konsumsi protein hewani masih tergolong rendah. Hal ini diakibatkan oleh tingginya harga protein hewani, yakni 120 ribu per $\mathrm{kg}$ (liputan6.com, 2016). Jika dibiarkan, hal ini akan menjadi penyebab kekurangan gizi. Salah satu alternatif untuk mengatasi permasalahan ini ialah memberikan alternatif pengganti daging dengan bahan dasar rolade yang tidak mahal namun kandungan gizinya tidak kalah, yakni seperti kacang kedelai.

Kedelai dipilih sebagai bahan baku makanan yang bergizi karena memiliki kandungan gizi yang tinggi. Dalam 100 gram biji kedelai mengandung 20,00 g air, 30,90 g protein, 15,10 g lemak, 30,10 g karbohidrat, 0,7-2,6 g abu dan 268,00 kJ energi (C. Budimarwanti, 2010). Kebutuhan protein sebesar 55 gram per hari dapat dipenuhi dengan makanan yang berasal dari kedelai sebanyak 157,14 gram. (Radiyati, 1992). Pengembangan produk olahan kedelai seperti tempe belum banyak diinovasikan pengolahannya.
Tempe mengandung 20,8 gram protein, 201 kalori, 8,8 gram lemak, 155 mg kalsium (Depkes RI, 1991 dalam BSN, 2012). Pengolahan tempe sudah banyak dikembangkan seperti nugget tempe, susu tempe, kripik, kerupuk, dan rolade tempe. Rolade tempe dapat dikembangkan sebagai alternatif pengganti bahan baku daging pada rolade tempe.

Rolade tempe pada umumnya sama pada proses pembuatannya, yang membedakan ialah bahan baku dari rolade secara umum. Olahan rolade tempe umumnya ditambahkan aneka sayuran seperti wortel, seledri, brokoli. Salah satu sayuran yang belum diujikan dalam olahan rolade tempe ialah jagung manis (Zea Mays Saccharata). Penambahan jagung manis didalam rolade ini diharapkan sebagai bahan tambahan (filler) yang berfungsi mengikat stabilitas emulsi, meningkatkan daya mengikat air, meningkatkan cita rasa, mengurangi susut selama pengolahan dan mengurangi biaya produksi (Aditia, 2004).

Adanya penelitian ini bertujuan untuk menguji pengaruh penambahan jagung manis (Zea Mays Saccharata) terhadap sifat fisik dan akseptabilitas pada rolade tempe. Selain itu, bertujuan untuk memberikan inovasi penggunaan protein nabati terhadap makanan rolade di pasaran. Adapun manfaat dari hasil penelitian ini diharapkan dapat memberikan sifat fisik dan akseptabilitas dari rolade yang terbaik dan paling 
disukai masyarakat jika ditambahkan jagung manis.

\section{METODE PENELITIAN}

Penelitian ini dilakukan menggunakan metode Studi literatur, Simple Random Sampling, dan Eksperimen dengan Rancangan Acak Lengkap. Penelitian ini menggunakan 5 perlakuan yaitu lama penggilingan 1 menit (R1), lama penggilingan 2 menit (R2), lama penggilingan 3 menit (R3), lama penggilingan 4 menit (R4) dan lama penggilingan 5 menit (R5) dan setiap perlakuan diulang sebanyak 4 kali. Data diolah dengan Analisis ANAVA one way untuk mengetahui pengaruh perlakuan, sedangkan untuk mengetahui perbedaan antara perlakuan digunakan Uji Wilayah Berganda Duncan. Pengujian tersebut digunakan untuk mengetahui apakah penggunaan jagung berpengaruh terhadap rolade tempe dengan menguji sifat fisik dan akseptabilitas.

Pembuatan rolade dengan menggunakan bahan-bahan yang meliputi tempe kedelai, jagung manis, air, aquades, telor, sayuran, minyak goreng, kulit lumpia, bawang merah goreng $1 \mathrm{sdm}$, bawang putih cincang halus 2 siung, merica, gula pasir, seledri, garam, cabai. Alat-alat yang digunakan dalam penelitian ini ialah panci, kompor, sendok, pisau, blender, piring / nampan, timbangan, oven, heating mantle, plastik $1 / 2$ kiloan, timbangan.

\section{HASIL DAN PEMBAHASAN}

\section{Uji Organoleptik oleh Para Ahli}

Berdasarkan hasil pengamatan 4 ahli

$\{2$ orang bidang gizi (Pak Alsuhendra alumni IPB dan $\mathrm{Bu}$ Irda alumni Malaysia) , 1 orang tata boga $(\mathrm{Bu}$ Sachriani Kepala Jurusan Tata Boga), 1 orang biokimia $(\mathrm{Bu} \quad$ Irma $)\}$ setelah dilakukan eksperimen pembuatan rolade tempe dengan 4 sampel perbandingan tempe dan jagung yaitu sampel A1 (85:15), sampel A3 (70:30), sampel A5 (55:45), sampel A0 (Kontrol atau tanpa penambahan jagung). Hasil percobaan ditunjukkan oleh tabel 4.1.

Tabel 4.1. Hasil pengamatan uji organoleptik rolade tempe oleh para ahli

\begin{tabular}{|l|l|l|l|l|}
\hline \multirow{2}{*}{ Uji } & \multicolumn{4}{|c|}{ Perlakuan Sampel pada Penggilingan 5 Menit (R5) } \\
\cline { 2 - 5 } & \multicolumn{1}{|c|}{ A0 } & \multicolumn{1}{c|}{ A1 } & \multicolumn{1}{c|}{ A5 } \\
\hline Warna & Cokelat & Cokelat pucat & Cokelat & Golden \\
\hline Rasa & Tidak Gurih & $\begin{array}{l}\text { Kurang Gurih } \\
\text { dan kurang } \\
\text { manis }\end{array}$ & $\begin{array}{l}\text { Gurih dan } \\
\text { manis }\end{array}$ & $\begin{array}{l}\text { Gurih dan } \\
\text { lebih manis }\end{array}$ \\
\hline Aroma & Kurang Sedap & Kurang Sedap & Sedap & Sedap \\
\hline Tekstur & Tidak empuk & $\begin{array}{l}\text { Kurang } \\
\text { empuk dan } \\
\text { lebih lunak }\end{array}$ & $\begin{array}{l}\text { Empuk dan } \\
\text { kurang padat }\end{array}$ & $\begin{array}{l}\text { Empuk dan } \\
\text { padat }\end{array}$ \\
\hline
\end{tabular}


Tabel 4.1. menyatakan bahwa rolade tempe pada sampel I (Kontrol atau tanpa b penambahan jagung) menghasilkan warna cokelat pada tampilan roladenya, rasanya gurih hanya rasa tempe yang dicampur dengan bumbu yang telah diaduk, aromanya sedap khas tempe, dan teksturnya padat. Sampel II (85:15) warnanya cokelat pucat. Sampel III (70:30) menghasilkan warna cokelat setelah dilakukan penggorengan rolade, aromanya sedap, teksturnya empuk, kurang padat, rasanya gurih dan manis. Sampel IV (55:45) menghasilkan warna cokelat setelah dilakukan penggorengan rolade, rasanya gurih dan lebih manis.
Rolade tempe yang sudah siap disajikan diuji coba kepada beberapa responden. Semua responden mencoba semua sampel dan membandingkan antara satu sampel dengan sampel yang lainnya. Hasil dari beberapa responden menyatakan bahwa mereka suka dengan rolade tempe dengan penambahan jagung disebabkan rasanya tidak hanya gurih tetapi juga rasa manis yang membuat responden suka dengan rolade tempenya.

\section{Uji Susut Masak}

Hasil pengujian susut masak yang telah dilakukan dengan menggunakan empat sampel lama penggilingin ke-5 dapat dilihat pada tabel 4.2.

Tabel 4.2. Hasil pengamatan uji keempukan rolade tempe

\begin{tabular}{|c|c|c|c|c|}
\hline \multirow{2}{*}{$\begin{array}{c}\text { Pengujian } \\
\text { (Rolade } \\
\text { Tempe : } \\
\text { Jagung } \\
\text { Manis) }\end{array}$} & \multicolumn{4}{|c|}{ Perhitungan Uji Susut Masak } \\
\hline & $\begin{array}{c}\text { Massa } \\
\text { Sebelum } \\
\text { Dimasak } \\
(W 1)\end{array}$ & $\begin{array}{c}\text { Massa } \\
\text { Sesudah } \\
\text { Dimasak } \\
\text { (W2) }\end{array}$ & $\begin{array}{c}\text { Selisih } \\
\text { Massa } \\
\text { Rolade } \\
\text { Tempe }(\Delta \mathbf{W})\end{array}$ & $\% \mathrm{~W}$ \\
\hline A0 & $\begin{array}{l}235,00 \\
\mathrm{~mm} / \mathrm{g} / \mathrm{s} \\
235,72 \\
\mathrm{~mm} / \mathrm{g} / \mathrm{s} \\
235,80 \\
\mathrm{~mm} / \mathrm{g} / \mathrm{s}\end{array}$ & $\begin{array}{l}119,05 \mathrm{~mm} / \mathrm{g} / \mathrm{s} \\
120,25 \mathrm{~mm} / \mathrm{g} / \mathrm{s} \\
120,73 \mathrm{~mm} / \mathrm{g} / \mathrm{s}\end{array}$ & $\begin{array}{l}115,95 \mathrm{~mm} / \mathrm{g} / \mathrm{s} \\
115,47 \mathrm{~mm} / \mathrm{g} / \mathrm{s} \\
115,07 \mathrm{~mm} / \mathrm{g} / \mathrm{s}\end{array}$ & $\begin{array}{l}49,34 \% \\
48,99 \% \\
48,80 \%\end{array}$ \\
\hline$\overline{A 1}$ & $\begin{array}{l}242,42 \\
\mathrm{~mm} / \mathrm{g} / \mathrm{s} \\
243,50 \\
\mathrm{~mm} / \mathrm{g} / \mathrm{s} \\
243,50 \\
\mathrm{~mm} / \mathrm{g} / \mathrm{s}\end{array}$ & $\begin{array}{l}176,20 \mathrm{~mm} / \mathrm{g} / \mathrm{s} \\
177,20 \mathrm{~mm} / \mathrm{g} / \mathrm{s} \\
177,20 \mathrm{~mm} / \mathrm{g} / \mathrm{s}\end{array}$ & $\begin{array}{l}66,22 \mathrm{~mm} / \mathrm{g} / \mathrm{s} \\
66,30 \mathrm{~mm} / \mathrm{g} / \mathrm{s} \\
66,30 \mathrm{~mm} / \mathrm{g} / \mathrm{s}\end{array}$ & $\begin{array}{l}27,32 \% \\
27,23 \% \\
27,23 \%\end{array}$ \\
\hline $\mathbf{A 3}$ & $\begin{array}{l}278,20 \\
\mathrm{~mm} / \mathrm{g} / \mathrm{s} \\
290,20 \\
\mathrm{~mm} / \mathrm{g} / \mathrm{s} \\
290,35 \\
\mathrm{~mm} / \mathrm{g} / \mathrm{s}\end{array}$ & $\begin{array}{l}208,45 \mathrm{~mm} / \mathrm{g} / \mathrm{s} \\
220,45 \mathrm{~mm} / \mathrm{g} / \mathrm{s} \\
220,45 \mathrm{~mm} / \mathrm{g} / \mathrm{s}\end{array}$ & $\begin{array}{l}69,75 \mathrm{~mm} / \mathrm{g} / \mathrm{s} \\
69,75 \mathrm{~mm} / \mathrm{g} / \mathrm{s} \\
69,90 \mathrm{~mm} / \mathrm{g} / \mathrm{s}\end{array}$ & $\begin{array}{l}25,07 \% \\
25,03 \% \\
24,07 \%\end{array}$ \\
\hline $\mathbf{A 5}$ & 312,05 & $272,05 \mathrm{~mm} / \mathrm{g} / \mathrm{s}$ & $40,00 \mathrm{~mm} / \mathrm{g} / \mathrm{s}$ & $12,82 \%$ \\
\hline
\end{tabular}




\begin{tabular}{|l|l|l|l|l|}
\hline $\mathrm{mm} / \mathrm{g} / \mathrm{s}$ & $272,07 \mathrm{~mm} / \mathrm{g} / \mathrm{s}$ & $40,00 \mathrm{~mm} / \mathrm{g} / \mathrm{s}$ & $12,82 \%$ \\
312,07 & $272,06 \mathrm{~mm} / \mathrm{g} / \mathrm{s}$ & $40,00 \mathrm{~mm} / \mathrm{g} / \mathrm{s}$ & $12,82 \%$ \\
$\mathrm{~mm} / \mathrm{g} / \mathrm{s}$ & & & \\
312,06 & & & \\
$\mathrm{~mm} / \mathrm{g} / \mathrm{s}$ & & & \\
\hline
\end{tabular}

Penambahan jagung manis (Zea menjadi lebih empuk dan padat seperti Mays Saccharata) terhadap tempe rolade daging. Rata-rata susut masak rolade dapat mempengaruhi tekstur rolade tempe dengan berbagai perlakuan 4.3.

Tabel 4.3. Rata-rata susut masak rolade tempe dengan berbagai perlakuan

\begin{tabular}{ccc}
\hline Perlakuan & Rataan Susut Masak & Signifikansi $(0,05)$ \\
\hline A0 & $49,04 \%$ & $\mathrm{~A}$ \\
A1 & $27,26 \%$ & $\mathrm{Ab}$ \\
A3 & $25,06 \%$ & $\mathrm{Bc}$ \\
A5 & $12,82 \%$ & $\mathrm{C}$ \\
\hline
\end{tabular}

Tabel 4.4. Hasil pengamatan uji susut masak rolade tempe

\begin{tabular}{ccc}
\hline Pengujian & Pengamatan & \% Susut Masak \\
& & \\
\hline A0 & 175,20 & $49,34 \%$ \\
& 175,20 & $48,99 \%$ \\
& 175,20 & $48,80 \%$ \\
\hline $\mathbf{A 1}$ & 170,85 & $27,32 \%$ \\
& 169,85 & $27,23 \%$ \\
& 170,85 & $27,23 \%$ \\
\hline $\mathbf{A 3}$ & 168,25 & $25,07 \%$ \\
& 167,50 & $25,03 \%$ \\
& 167,50 & $24,07 \%$ \\
\hline $\mathbf{A 5}$ & 157,83 & $12,82 \%$ \\
& 156,64 & $12,82 \%$ \\
& 157,70 & $12,82 \%$ \\
\hline
\end{tabular}


Berdasarkan tabel 4.3. dijelaskan bahwa penambahan jagung manis $15 \%$ didapatkan rataan susut masak sebanyak $27,26 \%$, tetapi berbeda nyata lebih besar dengan penambahan jagung manis $30 \%$ didapatkan rataan susut masak sebanyak $25,06 \%$, tetapi berbeda nyata lebih besar dengan penambahan jagung manis $45 \%$ yang mendapatkan rataan susut masak sebanyak $12,82 \%$.

Data tabel 4.3 menyatakan rolade tempe dengan susut masak rendah akan mengalami kehilangan nutrisi lebih sedikit selama pemasakan jika dibandingkan dengan rolade tempe dengan susut masak tinggi mempunyai kualitas yang lebih baik. Hal ini sesuai dengan pandapat Soeparno (2005) bahwa rolade tempe dengan susut masak yang lebih rendah akan memiliki kualitas lebih baik daripada rolade tempe dengan susut masak lebih tinggi, karena kehilangan nutrisi selama pemasakan menjadi lebih sedikit. Sehingga perlakuan A5 yang paling baik susut masaknya.

\section{Uji Keempukan}

Hasil pengujian keempukan yang telah dilakukan dengan menggunakan empat sampel lama penggilingin ke-5 dapat dilihat pada tabel 4.3. Berdasarkan tabel 4.4. menyatakan bahwa pada rolade tempe : jagung manis (Zea Mays Saccharata) dengan perbandingan pengujian A0 (100:0) mengalami tingkat keempukan lebih tinggi, sedangkan pada perbandingan pengujian A1 (85:15), A3 (70:30), dan A5 (55:45) mengalami tingkat keempukan lebih rendah jika dibandingkan dengan kontrol. Hal tersebut karena disebabkan oleh adanya penambahan jagung manis (Zea Mays Saccharata) pada pengujian A1, A3, dan A5.

Tabel 4.5. Rata-rata keempukan rolade tempe dengan berbagai perlakuan

\begin{tabular}{ccc}
\hline Perlakuan & Rataan Keempukan & Signifikansi $(0,05)$ \\
\hline A0 & 175,20 & A \\
A1 & 170,52 & A \\
A3 & 167,75 & B \\
A5 & 157,39 & B \\
\hline
\end{tabular}

Rerata keempukan rolade tempe dengan berbagai perlakuan ditunjukkan oleh tabel 4.5. Berdasarkan tabel 4.5. dijelaskan bahwa keempukan rolade tempe dengan panambahan jagung manis $15 \%$ didapatkan rataan keempukan sebanyak $170,52 \%$, tetapi penambahan jagung manis $30 \%$ didapatkan rataan keempukan sebanyak $167,75 \%$, tetapi berbeda nyata lebih besar dengan penambahan jagung manis $45 \%$ yang mendapatkan rataan keempukan sebanyak 157,39\%. Keadaan ini disebabkan karena pemanasan pati akan terbentuk suatu proses gelatinisasi. Oleh sebab itu, produk yang dihasilkan juga menjadi padat. 


\section{Akseptabilitas oleh Responden}

Uji akseptabilitas ini bertujuan untuk menguji kelayakan dan mengetahui pendapat beberapa mahasiswa UNJ (calon konsumen) tentang produk makanan rolade tempe yang diinovasikan dengan penambahan jagung manis (Zea
Mays Saccharata). Uji akseptabilitas ini dilakukan oleh 70 orang mahasiswa S1 UNJ, yaitu 28 orang dari mahasiswa S1 UNJ (KPM) dan 42 orang dari mahasiswa S1 UNJ (non-KPM) yang diambil secara acak di fakultas masingmasing.

Tabel 4.6. Hasil Uji Akseptabilitas Warna Rolade Tempe

\section{Warna}

\section{Duncan}

\begin{tabular}{|c|c|c|c|c|c|}
\hline \multirow{2}{*}{$\begin{array}{l}\text { konsentrasi } \\
\text { T/JM }\end{array}$} & \multirow[b]{2}{*}{$\mathrm{N}$} & \multicolumn{4}{|c|}{ Subset for alpha $=0.05$} \\
\hline & & 1 & 2 & 3 & 4 \\
\hline Control & 70 & 2.06 & & & \\
\hline $85 / 15$ & 70 & & 2.97 & & \\
\hline $70 / 30$ & 70 & & & 3.87 & \\
\hline $55 / 45$ & 70 & & & & 4.14 \\
\hline Sig. & & 1.000 & 1.000 & 1.000 & 1.000 \\
\hline
\end{tabular}

Means for groups in homogeneous subsets are displayed.

Penilaian pada uji akseptabilitas ini memiliki empat indikator dengan empat sampel. Empat indikator tersebut meliputi warna, rasa, aroma, dan tekstur. Berdasarkan tabel 4.6. dapat dijelaskan bahwa banyaknya responden hasil pengujian akseptibilitas warna dari produk rolade tempe yang diberi penambahan jagung antara 143 sampai 152 . Berdasarkan nilai yang diperoleh menunjukkan bahwa tingkat penerimaan konsumen terhadap produk ini diterima dengan baik. Namun, pada perlakuan A5, yakni penambahan jagung menunjukkan tingkat penerimaan warna yang lebih baik. Warna yang dihasilkan lebih disukai oleh konsumen. Pada perlakuan A1 (85:15) tingkat penerimaan konsumen sangat kecil. Sehingga, pada uji warna ini disimpulkan bahwa nilai skala numerik yang paling disukai ialah pada perlakuan A5, dengan penambahan jagung sebanyak 45\%. 
Tabel 4.7. Hasil Uji Akseptabilitas Rasa Rolade Tempe

\section{Rasa}

Duncan

\begin{tabular}{|c|c|c|c|c|c|}
\hline \multirow{2}{*}{$\begin{array}{l}\text { Konsentrasi } \\
\text { T/JM }\end{array}$} & \multirow[b]{2}{*}{$\mathrm{N}$} & \multicolumn{4}{|c|}{ Subset for alpha $=0.05$} \\
\hline & & 1 & 2 & 3 & 4 \\
\hline kontrol & 70 & 2.04 & & & \\
\hline $85 / 15$ & 70 & & 2.99 & & \\
\hline $70 / 30$ & 70 & & & 3.57 & \\
\hline $55 / 45$ & 70 & & & & 3.96 \\
\hline Sig. & & 1.000 & 1.000 & 1.000 & 1.000 \\
\hline
\end{tabular}

Means for groups in homogeneous subsets are displayed.

Tabel 4.7. menunjukkan bahwa hasil pengujian akseptabilitas rasa dari produk rolade tempe yang diberi penambahan jagung berkisar antara 208 sampai 220. Perlakuan A3 (70:30) menunjukkan tingkat penerimaan konsumen yang paling baik terhadap rasa dari produk yang dihasilkan. Penambahan jagung sebanyak 30 gram dinilai paling optimal memberikan rasa yang paling disukai oleh konsumen. Perlakuan A5 juga disukai namun banyaknya jagung yang ditambahkan memberikan hasil rolade tempe yang lebih manis dengan tekstur yang lebih kasar. Sedangkan perlakuan A0 tingkat penerimaan rasa yang dihasilkan sangat rendah. 
Tabel 4.8. Hasil Uji Akseptabilitas Aroma Rolade Tempe

\section{Aroma}

Duncan

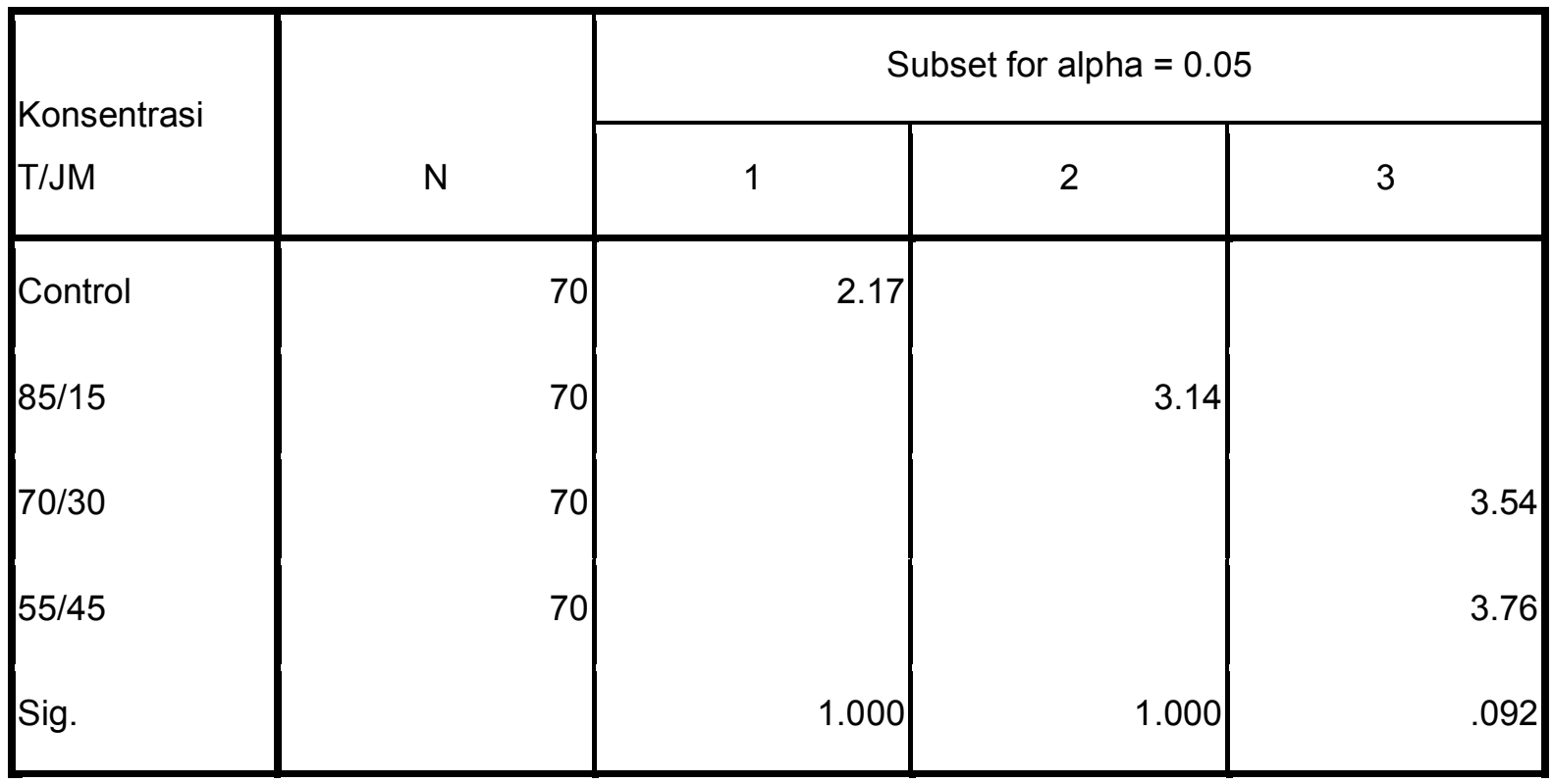

Means for groups in homogeneous subsets are displayed.

Data tabel 4.8. menunjukkan bahwa hasil pengujian akseptibilitas aroma dari produk rolade tempe yang diberi penambahan jagung berkisar antara 248 sampai 271. Perlakuan A0, tanpa diberi penambahan jagung menunjukkan tingkat penerimaan konsumen yang paling baik terhadap aroma dari produk yang dihasilkan. Penambahan jagung sebanyak 30 gram dinilai paling optimal memberikan rasa yang paling disukai oleh konsumen. Perlakuan A5 juga disukai namun banyaknya jagung memberikan hasil rolade tempe yang lebih manis dengan tekstur yang lebih kasar. Sedangkan perlakuan A0 tingkat penerimaan rasa yang dihasilkan sangat rendah. 
Tabel 4.9. Hasil Uji Akseptabilitas Tekstur Rolade Tempe

\begin{tabular}{|l|r|r|r|r|r|}
\multicolumn{1}{c|}{ ANOVA } \\
\cline { 2 - 7 } \multicolumn{1}{c|}{ Tekstur } & & & & & \\
\hline & Sum of Squares & Df & Mean Square & F & Sig. \\
\hline Between Groups & 139.743 & 3 & 46.581 & 61.413 & .000 \\
\hline Within Groups & 209.343 & 276 & .758 & & \\
\hline
\end{tabular}

Data pada tabel 4.9. menunjukkan bahwa hasil pengujian akseptibilitas tekstur dari produk rolade tempe yang diberi penambahan jagung berkisar antara 263 sampai 290. Perlakuan A0, tanpa diberi penambahan jagung menunjukkan tingkat penerimaan konsumen yang paling baik terhadap tekstur dari produk yang dihasilkan. Penambahan jagung sebanyak 30 gram tingkat penerimaan konsumen yang dihasilkan tidak baik. Dari hasil pengujian akseptibiltas yang telah dilakukan baik aroma, tekstur, warna menunjukkan tingkat penerimaan konsumen terhadap produk yang diberikan ialah pada penambahan jagung pada perlakuan $45 \%$ berat jagung. Semua data yang sudah diperoleh diuji dengan menggunakan analisa ANAVA one way dan dilanjutkan dengan uji Duncan.

\section{KESIMPULAN}

Penelitian ini menunjuukan bahwa adanya penambahan jagung dalam rolade tempe mempengaruhi cita rasa, aroma dan tekstur produk rolade. Uji susut masak menunjukkan perlakuan A5 menunjukkan hasil yang rendah, yakni 12,82\%. Rendahnya persen susut masak menunjukkan bahwa kehilangan nutrisi lebih sedikit selama pemasakan. Hal ini menunjukkan A5 memilik nutrisi yang baik. Pengujian akseptabilitas terhadap konsumen menunjukkan bahwa perlakuan A5 (55:45) mendapat respon yang sangat baik dari panelis. Sehingga, perlakuan A5 meupakan kondisi optimum penambahan jagung kedalam rolade tempe.

\section{DAFTAR PUSTAKA}

Aditia, E. L.. 2004. Sifat Fisik Kimia dan Palatabilitas Rolade Daging dengan Penambahan Berbagai Jenis Bahan Pengisi. Skripsi. Program Studi Teknologi Hasil Ternak. Departemen Ilmu Produksi ternak fakultas Peternakan. Bogor: IPB.

FAO Newsroom dalam A.Yakub. 2009. Responding ti The Food Crisis: Synthesis of Medium-term Measures Proposed in Interagency Assessments. FAO-WFPEU.

Helmi. 2010. Balita Gizi Buruk di NTT Masih Tinggi. Diakses pada 10 
April 2016, dari www.politikindonesia.com.

Palapasari. 2002. Klasifikasi Jagung Manis (Zae Mays Saccharata) di Daerah Bogor. Skripsi. Bogor: IPB.

Pearson, A. M. dan F. W. Tauber. 1984. Processed Meats.The AVI Publishing Co. Inc. Westport, Connecticut.

Sudayasa, Putu. 2010. Faktor-Fator Penyebab Kekurangan Gizi pada Balita. Diakses pada 10 April 2016, dari www.puskel.com.

Widianarko. 2002. Tips Pangan "Teknologi, Nutrisi, dan Keamanan pangan". Jakarta: Grasindo.

Winarno, F.G. 2004. Kimia pangan dan Gizi. Jakarta: PT. Gramedia.

Yakub, A. 2011. Menyelamatkan

Pertanian dan Menjadmin Kedaulatan Pangan. Jakarta : Grasindo. 